Article

\title{
The Protective Role of Emotional Intelligence in Self-Stigma and Emotional Exhaustion of Family Members of People with Mental Disorders
}

\author{
Rubén Trigueros ${ }^{1}$, Noelia Navarro ${ }^{2}$, Adolfo J. Cangas ${ }^{2} \mathbb{D}$, Isabel Mercader ${ }^{3, *}$, \\ José M. Aguilar-Parra ${ }^{1, * \mathbb{D}}$, Josefa González-Santos ${ }^{4}$, Jerónimo J. González-Bernal ${ }^{4}$ and \\ Raúl Soto-Cámara ${ }^{4}$ (D) \\ 1 Department of Psychology, Hum 878 Research Team, Health Research Centre, University of Almeria, \\ 04120 Almeria, Spain; rtr088@ual.es \\ 2 Department of Psychology, Hum-760 Research Team, Health Research Centre, University of Almeria, \\ 04120 Almeria, Spain; nng777@ual.es (N.N.); ajcangas@ual.es (A.J.C.) \\ 3 Department of Psychology, University of Almeria, 04120 Almeria, Spain \\ 4 Department of Health Sciences, Cavidito Research Team, Health Research Centre, University of Burgos, \\ 09001 Burgos, Spain; mjgonzalez@ubu.es (J.G.-S.); jejavier@ubu.es (J.J.G.-B.); rscamara@ubu.es (R.S.-C.) \\ * Correspondence: imercade@ual.es (I.M.); jmaguilar@ual.es (J.M.A.-P.)
}

Received: 1 May 2020; Accepted: 7 June 2020; Published: 15 June 2020

\begin{abstract}
Parenting a child or teenager is not particularly easy for parents, and this becomes even more difficult if a child has a serious mental disorder. This situation places parents in a vulnerable position that leads to heightened feelings of guilt and emotional stress. Therefore, the aim of this study was to analyze the influence of the families' emotional intelligence on their own self-stigma and burnout. A total of 537 family members from Southern Spain who care for individuals with mental disorders participated in this study. To analyze the results of the study, a structural equation model was constructed. The results from the equation showed that emotional intelligence is negatively related to self-stigma and burnout. In turn, self-stigma is positively related to burnout syndrome. Thus, the findings indicate that emotional intelligence may have a protective role against self-stigma, which is closely related to burnout syndrome. The relevance of these results when designing interventions that work with the negative feelings produced by self-stigma and family burnout is discussed.
\end{abstract}

Keywords: emotional intelligence; self-stigma; burnout; caregiver; mental health

\section{Introduction}

Emotional intelligence (EI), along with its possible effects on other variables, is a topic of deep study as it is linked to prosocial behavior for social interaction [1] and civic attitudes [2], emotional self-regulation skills [3], self-esteem, leadership, psychological adjustment [4], and stress management [5]. EI is also a protective factor for dissociative and antisocial behavior [6], is used to promote co-existence among peers, and allows individuals to contribute to the enhancement of thinking and other cognitive skills, thus increasing academic performance [7-10]. As a result, interest is growing in the development of emotional education programs that are aimed primarily at children and adolescents $[11,12]$.

EI can be understood as the ability to recognize our own feelings and the feelings of others to motivate ourselves and to properly manage the relationships we have with ourselves and with others [13]. This is a deliberate process that requires the ability to attend to and perceive feelings accurately, the assimilation and proper understanding of such feelings, and the ability to regulate and 
modify our own or others' moods in a voluntary manner [14,15]. As such, EI allows for improvements in relationships with oneself, with others, and with one's environment as a reliable indicator of psychological adjustment [16].

One of the great challenges in mental health intervention is the clarification of the nature and intervention of self-stigma, that is, the acceptance of social stigma [17], a subjective process characterized by the approval of stereotypes about mental disorders, negative feelings about oneself, and maladaptive behaviors of self-discrimination [18]. Self-stigma, therefore, is a process imbued with a socio-cultural context that involves the transformation of identity or the application of stereotypes that result from an individual experience, perception, or anticipation of negative social reactions [19]. Consequently, among its many effects, self-stigma may lead to a demoralization with feelings of shame and decreased self-esteem, while promoting isolation and hindering one's request for help [20]. Likewise, consequences are also observed in the self-esteem and personal and social image of the person and their environment [21]. As a result, this produces a deep transformation of personal identity, which implies the substitution of the previous roles by those that adjust to the negative image coherent with the stigma. The consequences of such stigma have become so devastating that various proposals for intervention have been introduced to address the issue [22,23]. Although it has been studied mainly in those affected in the first person, that is, those who suffer from the disorder, these self-stigmatizing effects also extend to those closest to them [24]. These close individuals are also usually the ones who assume the care or the costs for those with the disorder, which generates physical repercussions (e.g., fatigue, exhaustion), as well as economic and, most importantly, social ones, as these people are excluded from various areas (e.g., employment, education, etc.) [25,26].

Often, the lack of knowledge that family members have about the etiology of mental disorders places them in a position of vulnerability that increases the credibility of the theories that blame them for the suffering of their loved one [27]. Because it is often encouraged by the media, to this day, there is still a widely believed theory that parenting patterns and interactions in the family nucleus play a determining role in the development of disorders in children. This would consequently lead to the internalization of a family's role as an etiological agent which is associated with feelings of guilt and shame [28]. In this sense, the relatives of people with psychological disorders could refuse or avoid interpersonal relationships in anticipation of a possible rejection or marginalization based on the attributions that the general population makes about these problems [24], further diminishing their self-esteem and compromising their general states of mind. Among the wide and varied range of strategies, reactions, and attitudes displayed by family members are total or partial concealment of the disorder, an attitude of denial or abandonment or, on the contrary, paternalistic attitudes toward the disabled patients [29].

Although EI and self-stigma have not been directly linked to one another, they may be closely related. The relationship between EI and psychopathologies such as depression and anxiety, which share the presence of negative attributions and other aversive cognitions with self-stigma, is already well proven in the literature. A high level of EI would be a protective factor against depressive situations [30] by favoring the perception of emotions, detecting negative moods, and promoting life satisfaction [31,32]. The literature notes that students with good emotional skills are protected from any discomfort affecting their mental health, which would favor a better quality of life and enhance their human development [33]. EI would be a positive psychological factor that would enable the creation of a balance between stressful life events and adaptive skills [34]. In contrast, low levels of EI were found to correlate with the development of depressive symptoms [35-37].

More specific to self-stigma, possessing adequate skills to recognize and identify the emotions of others, as well as knowing how to manage this information, could be an important protective factor in this type of situation. A lack or scarcity of skills to recognize one's own emotions and those of others, would become a risk factor that would aggravate a potential self-stigma situation. All of this translates into significant psychological repercussions with family members suffering rejection and marginalization, aggravated by the prospect that the situation will not improve in the future as they 
would like [38]. The harmful repercussions of self-stigma, as mentioned above, have been amply demonstrated [39-41]. The impact on the family is high, often with first-degree relatives and close friends assuming the role of caregiver and supporter of the person who suffers mental disorders. Family members and other informal caregivers face situations that cause stress and anxiety, which inevitably disrupt their quality of life. In the case of people with mental disorders, it is estimated that $72 \%$ of caregivers are family members [42]. Not surprisingly, the concept of comprehensive rehabilitation involves the therapeutic alliance between family, patient, and professionals. The caregiver may develop feelings of loss as well as the decline in their own physical or mental health.

In this sense, burnout syndrome (BS) is a phenomenon long studied in the world of work [43-45]. Recognized as an occupational risk factor by the World Health Organization [46], BS, annihilation syndrome, or emotional exhaustion syndrome, seriously affects an individual's quality of life and mental health [47]. If it is sustained over time, BS can lead to depersonalization and dehumanization, which seriously hinders personal fulfillment [48], erodes self-esteem, and increases stress [49]. This emotional exhaustion is the central element, and is often accompanied by distraction, a feeling of reduced competence, low motivation, and the development of dysfunctional attitudes toward tasks to be performed [50]. Several studies reported the presence of physical and psychological disorders secondary to the care of a family member [51], which has consequences on their relationship with the dependent family member, interfering with the recovery process.

Although the interrelationship between these three variables has not been studied directly to date, we hypothesized that EI, self-stigma, and BS are closely linked. Therefore, the aim of the present study was to analyze the influence of emotional intelligence on the self-stigma and burnout of families in charge of relatives with severe mental disorders. Therefore, we hypothesized that the emotional intelligence of the relatives of those with mental disorders will have a negative influence on their own self-stigma and burnout. Conversely, the self-stigma of the relatives will positively influence their burnout.

\section{Method}

\subsection{Participants}

This study involved 537 parents aged 43 to 65 years $(M=51.32, \mathrm{SD}=3.31$ years) from the south area of Spain. The criteria for participation were to be in charge of a child with a mental disorder (such as schizophrenia, schizoaffective disorder, borderline personality disorder, and bipolar disorder) and to provide informed consent for the study to occur. The selection of the sample was incidental non-probabilistic.

The age of the participants ranged from 16 to 32 years. In relation to their pharmacological treatment, $81.4 \%$ were taking some type of antipsychotic at the time of starting the program, alone or combined with others, first or second generation. A total of $12.1 \%$ were taking another type of medication not considered an antipsychotic, and only one person (6.5\%) was not taking any type of psychotic medication on the date indicated.

Moreover, $42 \%$ of the sample also had, as an accessory to antipsychotic medication, treatment consisting of benzodiazepines such as anxiolytics, hypnotics, anticonvulsants, relaxants, etc. As well, $28.1 \%$ were taking medications considered to be mood or mood stabilizers, $24.3 \%$ were taking anticholinergic medications, and $36.6 \%$ were taking antidepressant medications. Finally, $39.1 \%$ of the children had some kind of treatment related to somatic diseases such as diabetes, hypercholesterolemia, hypertension, etc. 


\subsection{Measurements}

\subsubsection{Emotional Intelligence}

The Spanish version of the Trait Meta-Mood Scale (TMMS-24) was used [4]. This is a self-report measure of emotional intelligence, known as perceived emotional intelligence [5], and is composed of 24 items distributed among three subscales: attention (e.g., "I usually worry a lot about how I feel"), clarity (e.g., "I'm clear about my feelings"), and reparation of emotions (e.g., "I have a lot of energy when I feel happy"). Each of the subscales consists of 8 items. The scale is answered in the form of a Likert scale, measuring from 1 (not at all according) to 5 (completely in agreement).

\subsubsection{Family Self-Stigma Scale}

The Self-Stigma in Relatives of people with Mental Illness (SSRMI) by Morris et al., [52] validated and adapted to the Spanish context by Trigueros et al. [53], was used. This questionnaire begins with:

The following questions ask how you currently feel about your child's mental illness. Although we use the term "mental illness", think about this in whatever way you feel most comfortable. If you have had a diagnosis of mental illness yourself, when answering the questions, please focus on how you feel about your family member with a mental illness, rather than on your own diagnosis. Check whether you strongly disagree, disagree, agree or strongly agree.

It consists of 30 items, divided into five factors: stereotyping (e.g., "my family member's mental illness reflects negatively on me"), discrimination (e.g., "I would feel comfortable telling my friends that my family member has a mental illness"), separation (e.g., "I need to hide my family member's mental illness"), culpability (e.g., "I feel guilty because my family member has a mental illness"), and devaluation (e.g., "I feel embarrassed to have a family member with a mental illness"). The participants were asked to indicate their answers by ranking each statement on the Likert scale from 1 (totally disagree) to 5 (totally agree).

\subsubsection{Burnout}

The Maslach Burnout Inventory by Maslach and Jackson [54] was used, validated, and adapted to the Spanish context by Seisdedos [55]. This questionnaire consists of 22 items distributed among three factors: emotional exhaustion (e.g., "I feel emotionally drained"), depersonalization (e.g., "I think I treat some people as if they were impersonal objects"), and personal accomplishment (e.g., "I feel very energetic"). Adults responded using a Likert scale ranging from 0 (never) to 6 (every day).

\subsection{Procedure}

Firstly, various medical centers and associations in the community of Madrid and Andalusia were contacted to request their collaboration, informing them beforehand of the objective of the research. Family members were required to sign the informed consent form to participate in the study. The administration of the questionnaire was carried out under the supervision of the principal investigator of this study, with extensive experience in the world of research, who explained and resolved the doubts that arose when completing it. Anonymity and confidentiality of the data were guaranteed. The application of the questionnaire was carried out in the clinical services. The estimated time for participants to complete the questionnaires was $15 \mathrm{~min}$.

\section{Data Analysis}

In this study, descriptive statistical analyses, bivariate correlations, and reliability analyses were performed using the statistical program SPSS v.24, and in addition, a structural equation model (SEM) was constructed using the program AMOS v.22 to test the relationships established in the hypothesised model. 
To develop the hypothesised model (Figure 1), the maximum likelihood estimation method was used together with the bootstrapping procedure. The estimators were not affected by the lack of normality, so they were considered robust. To assess the model tested, several fit indices were considered: $\chi^{2} / \mathrm{df}$ (degrees of freedom), comparative fit index (CFI), incremental fit index (IFI), root mean square error of approximation (RMSEA) plus its confidence interval (CI) at $90 \%$, and standardized root mean square residual (SRMR). Values of $\chi^{2} / \mathrm{df}$ less than 3, values for the CFI close to or above 0.95 , and RMSEA and SRMR values close to or below 0.06 and 0.08 , respectively, were considered as an indication of an adequate fit of the model to the data [56]. However, Marsh et al. [57] stated that these cut-off values should be interpreted with caution, as they are too restrictive and difficult to achieve when testing complex models.

\section{Results}

\subsection{Preliminary Analysis}

The descriptive statistics and bivariate correlations can be seen in Table 1. The correlation analyses reflected a significant association between each of the factors that made up this study. Reliability scores across Cronbach's $\alpha$ gave scores above 0.70 .

Table 1. Descriptive statistics, bivariate correlations, and reliability analysis.

\begin{tabular}{cccccccc}
\hline Factors & $\mathbf{M}$ & SD & Range & $\alpha$ & $\mathbf{1}$ & $\mathbf{2}$ & $\mathbf{3}$ \\
\hline 1. Emotional Intelligence & 3.82 & 0.86 & $1-5$ & 0.79 & & $-0.40^{* * *}$ & $-0.31^{* *}$ \\
2. Family Self-Stigma & 2.07 & 1.12 & $1-5$ & 0.84 & & $0.53^{* * *}$ \\
3. Burnout & 2.57 & 1.34 & $0-6$ & 0.82 & & \\
\hline \multicolumn{7}{c}{ Note: $^{* *} p<0.01 ; * * * 0001}$.
\end{tabular}

\subsection{Structural Equation Modeling}

Before testing the hypothesized model by means of SEM and by analyzing the relationships between the variables belonging to the model, the number of latent variables was reduced, with each one having at least two indicators due to the complexity of the model [58]. Specifically, the latent variables used were emotional intelligence, which included perception or attention to feelings, emotional understanding or clarity, and regulation or reparation of emotions [4]; burnout, which included emotional exhaustion, depersonalization, and personal fulfillment [55]; and self-stigma, which includes stereotypes, discrimination, separation, culpability, and devaluation (Trigueros et al, 2019).

Testing the hypothesised predictive relationship model (Figure 1) revealed the following adjustment rates: $\chi^{2}(41, \mathrm{~N}=537)=158.59, \chi 2 / \mathrm{df}=2.65, p<0.001 \mathrm{CFI}=0.96 ; \mathrm{IFI}=0.96$; RMSEA $=0.052$ $(C I 90 \%=0.049-0.058)$; and SRMR $=0.043$. These results were in line with the established parameters, so the proposed model was accepted as adequate. Similarly, the contribution of each of the factors to the prediction of other variables was examined through standardized regression weights. The following describes the relationships obtained between the different factors that compose the model:

(a) Emotional intelligence negatively predicted family self-stigma $(\beta=-0.52, p<0.001)$.

(b) Family self-stigma positively predicted burnout $(\beta=0.42, p<0.001)$.

(c) Emotional intelligence predicted burnout negatively $(\beta=-0.48, p<0.001)$. 


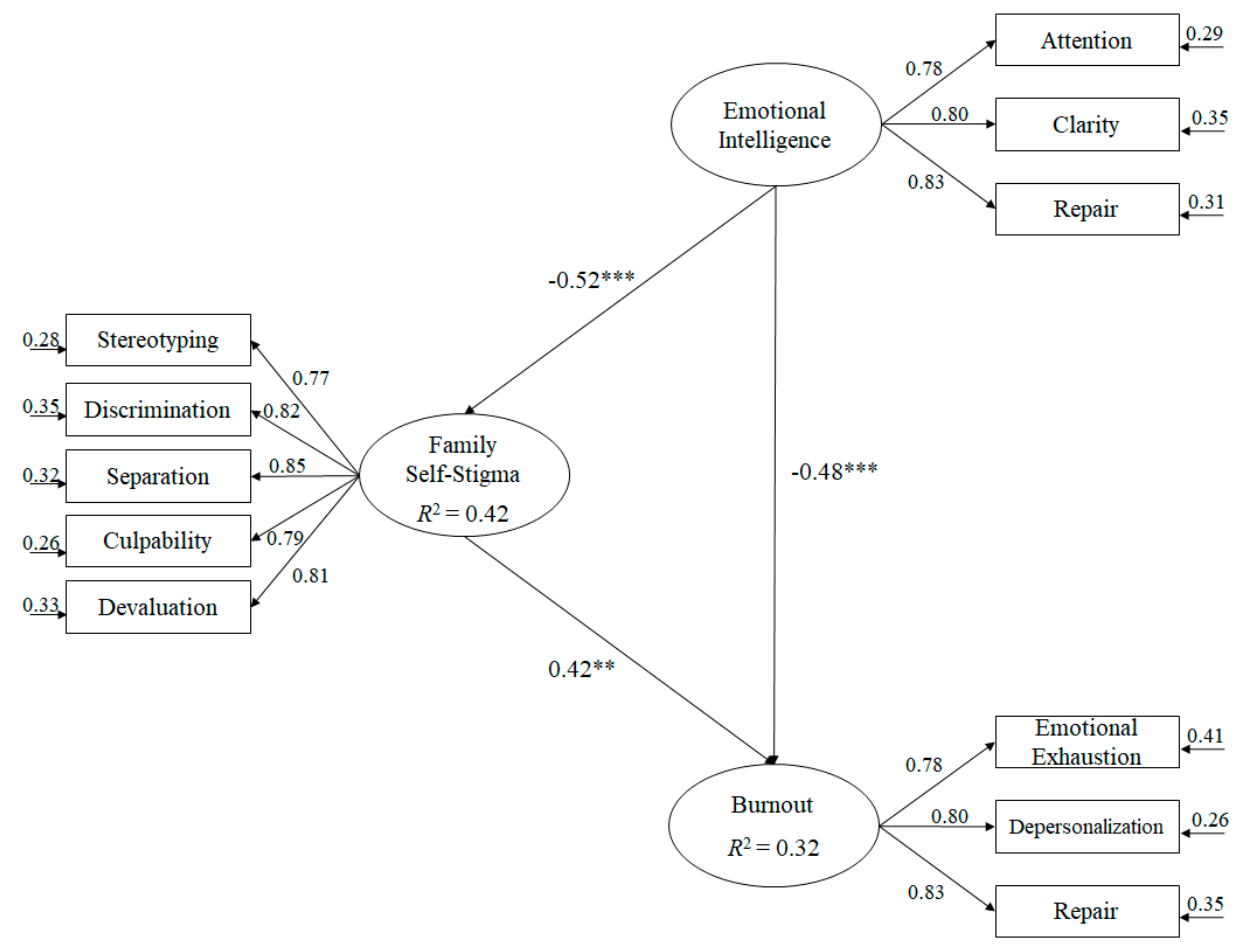

Figure 1. Hypothesised model where all variables are related to one another. All parameters were standardized and were statistically significant. Note: ${ }^{* *} p<0.001,{ }^{* *} p<0.01$.

\section{Discussion}

The aim of this study was to examine the possible relationship of EI on self-stigma and burnout in people with family members who have severe mental disorders. Initially, we hypothesized that EI would be negatively related to self-stigma and burnout, and self-stigma would in turn influence BS. The results confirm the existence of significant correlations between these variables with the reliability analysis yielding satisfactory results. Therefore, given that the adjustment were acceptable, we were able to affirm the accuracy of the proposed model.

The results showed how EI acts as a protective factor against self-stigma, given its negative relation to self-stigma. These findings are in line with previous studies, such as that by James [59] who, using a sample of adolescents who had committed a crime, showed that young people who had high emotional intelligence showed lower levels of self-stigma. In addition, other related studies point out that EI favors adaptation and the use of strategies to achieve goals and solve problems [60], or that it is connected to resilience [61].

With regard to self-stigmatizing factors (stereotyping, discrimination, separation, guilt, and devaluation), the positive relationship with the burnout was also confirmed. Previous studies on burnout showed that a high level of EI provides skills to adapt to depressive situations [30]. Being emotionally intelligent, among other skills, implies the ability to ensure that interpersonal relationships help individuals experience as many positive emotions as possible, and the ability to reduce negative emotions that may be produced by living with others [13]. In this way, EI would encourage the use of emotions in favor of more effective reasoning [62]. At the same time, EI would be a protective factor for the negative emotional charge $[63,64]$ present in self-stigma and BS. Thus, the internalization of a negative self-image, the anticipation of rejection, and the consequent social isolation (self-stigma) would aggravate the symptoms of what is known as caregiver syndrome [65]. This situation of burnout is further aggravated in many cases by factors, such as not receiving financial compensation [66], as well as by difficult situations that may arise from behavioral disorders in the dependent family member $[17,67]$. 
These results highlight the importance of promoting emotional intelligence in families who are responsible for the care of seriously mentally ill family members. In this sense, this family situation is traumatic on psychological and social levels and can become more acute over time since moral judgment and fear of the danger to the family member are important sources of discrimination. Therefore, it is important to be equipped with skills to face the world and its challenges so that, ultimately, these individuals do not suffer.

Despite the results achieved in this study, there are a number of limitations that must be considered. The first relates to the selection of the sample, which was cross-sectional, so the results obtained do not allow causal relationships to be established. As a result, the explanations given in the discussion have only been offered so that they may be reinterpreted according to each reader. In addition, future studies should, through qualitative studies and discussion groups, analyze how family members feel when they have people with mental disorders under their care, as it would provide a more holistic view of the relationships between parents and their child/children. In addition, future studies should compare families with a child/ children with severe mental illness and families with children who do not have severe mental illness.

\section{Conclusions}

Although it is not possible to precisely determine the degree to which EI plays a role in coping with mental difficulties or in preserving a positive self-image in the face of emotional exhaustion, the integration of adequate emotional strategies could be an important protective factor $[68,69]$. In this sense, emotionally intelligent people would have more practical skills to execute tasks and solve problems of an emotional nature [15]. These skills could be important for working on relational aspects in familial settings, thus reducing possible difficulties.

Author Contributions: All authors have contributed equally. All authors have read and agree to the published version of the manuscript.

Funding: This research received no external funding.

Conflicts of Interest: The authors declare no conflict of interest.

\section{References}

1. Engelberg, E.; Sjöberg, L. Internet use, social skills, and adjustment. Cyberpsychol. Behav. 2004, 1, 41-47. [CrossRef]

2. El-Khodary, B.; Samara, M. The mediating role of trait emotional intelligence, prosocial behaviour, parental support and parental psychological control on the relationship between war trauma, and PTSD and depression. J. Res. Personal. 2019, 81, 246-256. [CrossRef]

3. Cheung, R.Y.; Leung, M.C.; Chung, K.K.H.; Cheung, H.Y. Family risks and adolescent adjustment in Chinese contexts: Testing the mediating role of emotional intelligence. J. Child Fam. Stud. 2018, 12, 3887-3896. [CrossRef]

4. Extremera, N.; Mérida-López, S.; Sánchez-Álvarez, N.; Quintana-Orts, C.; Rey, L. A friend is a treasure: Emotional intelligence, workplace social support and teacher engagement. Prax. Saber 2019, 24, 69-92. [CrossRef]

5. Salovey, P.; Stroud, L.R.; Woolery, A.; Epel, E.S. Perceived emotional intelligence, stress reactivity, and symptom reports: Further explorations using the trait meta-mood scale. Psychol. Health 2002, 5, 611-627. [CrossRef]

6. Fink, K.; Cohen, J.; Slade, S. Integrating Prosocial Learning with Education Standards: School Climate Reform Initiatives; Routledge: New York, NY, USA, 2015.

7. Ashknasy, N.M.; Dasborough, M.T. Emotional Awareness and Emotional Intelligence in Leadership Teaching. J. Educ. Bus. 2003, 79, 18-22. [CrossRef]

8. Garg, R.; Levin, E.; Tremblay, L. Emotional intelligence: Impact on post-secondary academic achievement. Soc. Psychol. Educ. 2016, 3, 627-642. [CrossRef] 
9. MacCann, C.; Jiang, Y.; Brown, L.E.; Double, K.S.; Bucich, M.; Minbashian, A. Emotional intelligence predicts academic performance: A meta-analysis. Psychol. Bull. 2020, 2, 150. [CrossRef] [PubMed]

10. Thomas, C.L.; Cassady, J.C.; Heller, M.L. The influence of emotional intelligence, cognitive test anxiety, and coping strategies on undergraduate academic performance. Learn. Individ. Differ. 2017, 55, 40-48. [CrossRef]

11. Mestre, J.M.; Guil, R.; Martínez-Cabañas, F.; Larrán, C.; González, G. Validación de una prueba para evaluar la capacidad de percibir, expresar y valorar emociones en niños de la etapa infantil. Rev. Electrónica Interuniv. Form. Profr. 2011, 3, 37-54.

12. Cladellas, R.; Clariana, M.; Gotzens, C.; Badía, M.; Dezcallar, T. Patrones de descanso, actividades físico-deportivas extraescolares y rendimiento académico en niños y niñas de primaria. Rev. Psicol. Deporte 2015, 1, 0053-0059.

13. Goleman, D. Liderazgo. El Poder de la Inteligencia Emocional; B de Bolsillo: Barcelona, Spain, 2014.

14. Koole, S.L. The psychology of emotion regulation: An integrative review. Cogn. Emot. 2009, 1, 4-41. [CrossRef]

15. Mayer, J.D.; Salovey, P.; Caruso, D.R. Emotional Intelligence as Zeigeist, as Personality, and as Mental Ability. In The Handbook of Emotional Intelligence. Theory, Development, Assessment, and Application at Home, School, and in the Workplace; Bar-On, R., Parker, J.D.A., Eds.; Jossey-Bass: San Francisco, CA, USA, 2000; pp. $92-117$.

16. Guerrero-Barona, E.; Sánchez-Herrera, S.; Moreno-Manso, J.M.; Sosa-Baltasar, D.; Durán-Vinagre, M.Á. El autoconcepto y su relación con la inteligencia emocional y la ansiedad. Behav. Psychol. 2019, 3, 455-476.

17. Corrigan, P.W.; Bink, A.B.; Schmidt, A. Reducing Physical Illness Stigma: Insights from the Mental Illness Arena. In The Oxford Handbook of Stigma, Discrimination, and Health; Major, B., Dovidio, J.F., Link, B., Eds.; Oxford University Press: Oxford, UK, 2018.

18. Livingston, J.D.; Boyd, J.E. Correlates and consequences of internalized stigma for people living with mental illness: A systematic review and meta-analysis. Soc. Sci. Med. 2010, 12, 2150-2161. [CrossRef] [PubMed]

19. Muñoz, M.; Sanz, M.; Pérez-Santos, E. Estado del conocimiento sobre el estigma internalizado desde el modelo socio-cognitivo comportamental. Anu. Psicol. Clinica Salud. Annu. Clin. Health Psychol. 2011, 7, $41-50$.

20. López, M.; Laviana, M.; Fernández, L.; López, A.; Rodríguez, A.M.; Aparicio, A. La lucha contra el estigma y la discriminación en salud mental: Una estrategia compleja basada en la información disponible. Rev. Asoc. Española Neuropsiquiatría 2008, 1, 48-83. [CrossRef]

21. Gentile, A.; Servidio, R.; Caci, B.; Boca, S. Social stigma and self-esteem as mediators of the relationship between Body Mass Index and Internet addiction disorder. An exploratory study. Curr. Psychol. 2018, 1-9. [CrossRef]

22. Evans-Lacko, S.; Henderson, C.; Thornicroft, G.; McCrone, P. Economic evaluation of the anti-stigma social marketing campaign in England 2009-2011. Br. J. Psychiatry 2013, 55, s95-s101. [CrossRef]

23. Oexle, N.; Waldmann, T.; Staiger, T.; Xu, Z.; Ruesch, N. Mental illness stigma and suicidality: The role of public and individual stigma. Epidemiol. Psychiatr. Sci. 2018, 2, 169-175. [CrossRef]

24. Corrigan, P.W.; Nieweglowski, K. How does familiarity impact the stigma of mental illness? Clin. Psychol. Rev. 2019, 70, 40-50. [CrossRef]

25. Rüsch, N.; Zlati, A.; Black, G.; Thornicroft, G. Does the stigma of mental illness contribute to suicidality? Br. J. Psychiatry 2014, 4, 257-259. [CrossRef] [PubMed]

26. Persson, P.; Rossin-Slater, M. Family ruptures, stress, and the mental health of the next generation. Am. Econ. Rev. 2018, 4-5, 1214-1252. [CrossRef]

27. Thornicroft, G.; Mehta, N.; Clement, S.; Evans-Lacko, S.; Doherty, M.; Rose, D.; Koschorke, M.; Shidhaye, R.; O'Reilly, C.; Henderson, C. Evidence for effective interventions to reduce mental-health-related stigma and discrimination. Lancet 2016, 10023, 1123-1132. [CrossRef]

28. Muñoz, M.; Pérez Santos, E.; Crespo, M.; Guillen, A.I. Estigma y Enfermedad Mental. Available online: Biblioteca.ucm.es/ecsa/9788474919806.pdf (accessed on 8 April 2020).

29. Gabrielian, S.; Young, A.S.; Greenberg, J.M.; Bromley, E. Social support and housing transitions among homeless adults with serious mental illness and substance use disorders. Psychiatr. Rehabil. J. 2018, 3, 208. [CrossRef] [PubMed]

30. Maguire, R.; Egan, A.; Hyland, P.; Maguire, P. Engaging students emotionally: The role of emotional intelligence in predicting cognitive and affective engagement in higher education. High. Educ. Res. Dev. 2017, 2, 343-357. [CrossRef] 
31. Extremera, N.; Durán, A.; Rey, L. Perceived emotional intelligence and dispositional optimism-pessimism: Analyzing their role in predicting psychological adjustment among adolescents. Personal. Individ. Differ. 2007, 6, 1069-1079. [CrossRef]

32. Carvalho, V.S.; Guerrero, E.; Chambel, M.J. Emotional intelligence and health students' well-being: A two-wave study with students of medicine, physiotherapy and nursing. Nurse Educ. Today 2018, 63, 35-42. [CrossRef]

33. De Alba, U.R.; Colorado, Y.S. Relación entre inteligencia emocional, depresión y rendimiento académico en estudiantes de psicología. Psicogente 2012, 28, 348-359.

34. Salovey, P.; Mayer, J.D. Emotional intelligence. Imagin. Cogn. Personal. 1990, 3, 185-211. [CrossRef]

35. Salovey, P.; Woolery, A.; Mayer, J.D. Emotional intelligence: Conceptualization and measurement. In Blackwell Handbook of Social Psychology: Interpersonal Processes; John Wiley \& Sons: Hoboken, NJ, USA, 2001; pp. $279-307$.

36. Veytia, M.; Fajardo, R.; Guadarrama, R.; Escutia, N. Inteligencia Emocional: Factor positivo ante la depresión en adolescentes de bachillerato. Rev. Inf. Psicológicos 2016, 1, 35-50. [CrossRef]

37. Balluerka, N.; Aritzeta, A.; Gorostiaga, A.; Gartzia, L.; Soroa, G. Emotional intelligence and depressed mood in adolescence: A multilevel approach. Int. J. Clin. Health Psychol. 2013, 2, 110-117. [CrossRef]

38. Reever, K.E.; Mathieu, E.; Dennis, M.P.; Gitlin, L.N. Adult day services plus: Augmenting adult day centers with systematic care management for family caregivers. Alzheimer's Care Today 2004, 4, 332-339.

39. Ross, S.G.; Bruggeman, B.; Maldonado, M.; Deiling, M. Examining personal, perceived, treatment, and self-stigma in college students: The role of Parent beliefs and mental health literacy. J. Coll. Stud. Psychother. 2019, 1, 1-15. [CrossRef]

40. Lysaker, P.H.; Vohs, J.; Hasson-Ohayon, I.; Kukla, M.; Wierwille, J.; Dimaggio, G. Depression and insight in schizophrenia: Comparisons of levels of deficits in social cognition and metacognition and internalized stigma across three profiles. Schizophr. Res. 2013, 3, 18-23. [CrossRef]

41. Kamaradova, D.; Latalova, K.; Prasko, J.; Kubinek, R.; Vrbova, K.; Mainerova, B.; Tichackova, A. Connection between self-stigma, adherence to treatment, and discontinuation of medication. Patient Prefer. Adherence 2016, 10, 1289. [CrossRef]

42. European Federation of Associations of Families of People with Mental Illness, (EUFAMI); Annual Report; EUFAMI: De Haan, Bélgica, 2014; Available online: http://eufami.org/wp-content/uploads/2018/03/eufami-annualreport-2014-lr.pdf (accessed on 8 April 2020).

43. Freudenberger, H.J. Staff burnout. J. Soc. Issues 1974, 7, 159-164. [CrossRef]

44. Briones, C. Teorías performativas de la identidad y performatividad de las teorías. Tabula Rasa 2007, 6, 55-83. [CrossRef]

45. Valério, F.J.; Amorim, C.; Moser, A.M. A síndrome de Burnout em professores de Educação Física. Rev. Psicol. IMED 2009, 1, 127-136. [CrossRef]

46. WHO. Informe Sobre la Salud en el Mundo: 2000. Mejorar el Desempeño de los Sistemas de Salud; Organización Mundial de la Salud: Ginebra, Switzerland, 2000.

47. Aceves, G.A. Síndrome de burnout. Arch. Neurocienc. 2006, 4, 305-309.

48. Laschinger, H.; Grau, A. The Influence of Personal Dispositional Factors and Organizational Resources on Workplace Violence, Burnout, and Health Outcomes in New Graduate Nurses: A Cross-Sectional Study. Int. J. Nurs. Stud. 2012, 49, 282-291. [CrossRef]

49. Alarcon, G.; Eschleman, K.J.; Bowling, N.A. Relationship between Personality Variables and Burnout A Meta-Analysis. Work Stress 2009, 23, 244-263. [CrossRef]

50. Schaufeli, W.; Enzmann, D. The Burnout Companion to Study and Practice: A Critical Analysis; CRC Press: Boca Raton, FL, USA, 1998.

51. Son, J.; Erno, A.; Shea, D.G.; Femia, E.E.; Zarit, S.H.; Parris Stephens, M.A. The caregiver stress process and health outcomes. J. Aging Health 2007, 6, 871-887. [CrossRef] [PubMed]

52. Morris, E.; Hippman, C.; Murray, G.; Michalak, E.E.; Boyd, J.E.; Livingston, J.; Inglis, A.; Carrion, P.; Austin, J. Self-Stigma in Relatives of people with Mental Illness scale: Development and validation. Br. J. Psychiatry 2018, 212, 1-6. [CrossRef] [PubMed]

53. Trigueros, R.; Navarro, N.; Cangas, A.J.; Aguilar-Parra, J.M.; Ortiz, L. Adaptation and validation to the spanish context of the scale of self-stigma in relatives of people with mental illness. Ann. Psychol. 2019, 35, 371-377. [CrossRef] 
54. Maslach, C.; Jackson, S.E. The measurement of experienced burnout. J. Organ. Behav. 1981, 2, 99-113. [CrossRef]

55. Seisdedos, N. Inventario de Burnout de Maslach; TEA Ediciones: Madrid, Spain, 1997.

56. Hair, J.; Black, W.; Babin, B.; Anderson, R.; Tatham, R. Multivariate Data Analysis; Pearson/Prentice Hall: Upper Saddle River, NJ, USA, 2006.

57. Marsh, H.W.; Hau, K.T.; Wen, Z. In search of golden rules: Comment on hypothesis-testing approaches to setting cutoff values for fit indexes and dangers in overgeneralizing Hu and Bentler's (1999) findings. Struct. Equ. Model. 2004, 11, 320-341. [CrossRef]

58. McDonald, R.P.; Ho, M.H.R. Principles and practice in reporting structural equation analyses. Psychol. Methods 2002, 7, 64. [CrossRef]

59. James, C. Law student wellbeing: Benefits of promoting psychological literacy and self-awareness using mindfulness, strengths theory and emotional intelligence. Legal Educ. Rev. 2011, 21, 217.

60. Checa, P.; Fernández-Berrocal, P. The Role of Intelligence Quotient and Emotional Intelligence in Cognitive Control Processes. Front. Psychol. 2015, 6, 1853. [CrossRef]

61. Armstrong, A.R.; Galligan, R.F.; Critchley, C.R. Emotional intelligence and psychological resilience to negative life events. Personal. Individ. Differ. 2011, 51,331-336. [CrossRef]

62. Mayer, J.D.; Salovey, P. What is emotional intelligence? In Emotional Development and Emotional Intelligence: Educational Implications; Salovey, P., Sluyter, D.J., Eds.; Basic Books: New York, NY, USA, 1997; pp. 3-34.

63. Kircaburun, K.; Griffiths, M.D.; Billieux, J. Trait emotional intelligence and problematic online behaviors among adolescents: The mediating role of mindfulness, rumination, and depression. Personal. Individ. Differ. 2019, 139, 208-213. [CrossRef]

64. Martínez-Monteagudo, M.C.; Inglés, C.J.; Granados, L.; Aparisi, D.; García-Fernández, J.M. Trait emotional intelligence profiles, burnout, anxiety, depression, and stress in secondary education teachers. Personal. Individ. Differ. 2019, 142, 53-61. [CrossRef]

65. Barraza, R.; Muñoz, N.; Alfaro, M.; Álvarez, A.; Araya, V.; Villagra, J.; Contreras, A.M. Ansiedad, depresión, estrés y organización de la personalidad en estudiantes novatos de medicina y enfermería. Rev. Chil. Neuro-Psiquiatr. 2015, 4, 251-260. [CrossRef]

66. Soares, J.J.; Grossi, G.; Sundin, Ö. Burnout among women: Associations with demographic/socio-economic, work, life-style and health factors. Arch. Women's Ment. Health 2007, 2, 61-71. [CrossRef] [PubMed]

67. Eaton, K.; Stritzke, W.G.; Corrigan, P.W.; Ohan, J.L. Pathways to Self-Stigma in Parents of Children with a Mental Health Disorder. J. Child Fam. Stud. 2019, 29, 1732-1744. [CrossRef]

68. Díaz, T. El desarrollo de competencias socioemocionales y su evaluación como elementos clave en los planes de formación docente. Algunas conclusiones derivadas de la evaluación SIMCE 2011. Rev. Iberoam. Educ. 2014, 64, 73-98. [CrossRef]

69. Caruso, D.R. Emotional intelligence. In Encyclopedia of Industrial/Organizational Psychology; Rogelberg, S., Ed.; Sage: Thousand Oaks, CA, USA, 2006; pp. 180-182.

(C) 2020 by the authors. Licensee MDPI, Basel, Switzerland. This article is an open access article distributed under the terms and conditions of the Creative Commons Attribution (CC BY) license (http://creativecommons.org/licenses/by/4.0/). 